\title{
Mitochondrial DNA mutations in oxyphilic and chief cell parathyroid adenomas Jessica Costa-Guda1 ${ }^{1}$ Takehiko Tokura1, Sanford I Roth ${ }^{2}$ and Andrew Arnold*1
}

\author{
Address: ${ }^{1}$ Center for Molecular Medicine, University of Connecticut School of Medicine, 263 Farmington Ave, Farmington, Connecticut 06030- \\ 3101, USA and 2Department of Pathology, Harvard Medical School and Massachusetts General Hospital, Boston, Massachusetts 02114, USA \\ Email: Jessica Costa-Guda - costa@nso2.uchc.edu; Takehiko Tokura - ttokura@med.kawasaki-m.ac.jp; \\ Sanford I Roth - siroth@northwestern.edu; Andrew Arnold* - molecularmedicine@uchc.edu \\ * Corresponding author
}

Published: 4 October 2007

BMC Endocrine Disorders 2007, 7:8 doi:10.1186/1472-6823-7-8

This article is available from: http://www.biomedcentral.com/l472-6823/7/8

(c) 2007 Costa-Guda et al; licensee BioMed Central Ltd.

This is an Open Access article distributed under the terms of the Creative Commons Attribution License (http://creativecommons.org/licenses/by/2.0), which permits unrestricted use, distribution, and reproduction in any medium, provided the original work is properly cited.
Received: 21 March 2007

Accepted: 4 October 2007

\begin{abstract}
Background: The potential pathogenetic significance of mitochondrial DNA (mtDNA) mutations in tumorigenesis is controversial. We hypothesized that benign tumorigenesis of a slowly replicating tissue like the human parathyroid might constitute an especially fertile ground on which a selective advantage conferred by mtDNA mutation could be manifested and might contribute to the oxyphilic phenotype observed in a subset of parathyroid tumors.
\end{abstract}

Methods: We sought acquired mitochondrial DNA mutations by sequencing the entire $16.6 \mathrm{~kb}$ mitochondrial genome of each of thirty sporadic parathyroid adenomas ( 8 chief cell and 12 oxyphil cell), eight independent, polyclonal, parathyroid primary chief cell hyperplasias plus corresponding normal control samples, five normal parathyroid glands, and one normal thyroid gland.

Results: Twenty-seven somatic mutations were identified in 15 of 30 (9 of 12 oxyphil adenomas, 6 of 18 chief cell) parathyroid adenomas studied. No somatic mutations were observed in the hyperplastic parathyroid glands.

Conclusion: Features of the somatic mutations suggest that they may confer a selective advantage and contribute to the molecular pathogenesis of parathyroid adenomas. Importantly, the statistically significant differences in mutation prevalence in oxyphil vs. chief cell adenomas also suggest that mtDNA mutations may contribute to the oxyphil phenotype.

\section{Background}

Single parathyroid adenomas, which cause approximately $85 \%$ of the cases of primary hyperparathyroidism [1] are well-differentiated, benign, clonal tumors, which produce hypercalcemia through excessive secretion of parathyroid hormone (PTH). Activation of the cyclin D1 oncogene and inactivation of the MEN1 tumor suppressor gene are established pathogenetic contributors, but understanding of molecular pathogenesis in this disease remains incomplete. The mitochondrial genome has been identified as a possible target for somatic mutations that may promote tumorigenesis [2-10]. Mitochondrial abnormalities, including changes in structure, number, and respiratory enzyme components and transport systems, have been observed in many cancers. Homoplasmic somatic mutations of the mitochondrial genome have also been identi- 
fied in many tumor types [2-10]. However, the pathogenetic significance of the mutations detected in those tissues is unclear.

The human parathyroid is an intrinsically low-turnover tissue [11], as such, benign tumors arising from this tissue have relatively low proliferative rates. The mitochondrial genome is an especially attractive potential target for mutations that could drive tumorigenesis in such a tissue. Mitochondrial DNA replicates frequently and independently of the nuclear genome [12], and over many years the potential for enhanced DNA damage from locally generated reactive oxygen species (ROS) may further enhance the accumulation of somatic mutations in the mitochondrial genome.

In many endocrine organs, especially the parathyroid glands, with age, increasing numbers of oxyphil cells appear $[13,14]$. The oxyphil cells of normal parathyroid glands have a characteristic eosinophilic granular cytoplasm (Figure 1) which on electron microscopic examination is filled with abnormally shaped mitochondria $[15,16]$. In contrast to the chief cells, the oxyphil cells in normal glands lack the organelles associated with protein synthesis and secretion, and lack immunohistochemically identifiable chromogranin and PTH [16]. The majority of parathyroid adenomas are composed predominately of chief cells (Figure 1), however there is a subset of hyperfunctioning parathyroid adenomas that contain greater than $90 \%$ oxyphil cells and are classified as oxyphil adenomas These tumors, in addition to having a cytoplasm filled with abnormal mitochondria, contain the organelles of protein synthesis and secretion and contain histochemically identifiable PTH. While the molecular basis for this phenotypic change is unknown, it has been hypothesized that mitochondria may accumulate in oxyphil cells due to abnormalities of the mitochondrial genome[17], supported by the finding of increased numbers of oxyphil cells in normal glands with increasing age, analogous to increased mtDNA damage that occurs with aging [16].

We therefore sought acquired somatic mutations of the mitochondrial genome in both typical chief cell parathyroid adenomas and oxyphil cell parathyroid adenomas using an especially rigorous approach, and compared these findings with the mitochondrial genomes of normal and hyperplastic parathyroid glands.

\section{Methods}

\section{Patient and tumor samples}

Tissue samples were obtained, with Human Studies Institutional Review Board approval, from thirty-four patients who had undergone parathyroidectomy for management of primary hyperparathyroidism. Thirty samples were surgically and pathologically proven to be single parathyroid adenomas with no malignant features; of these, eighteen were determined to be typical chief cell adenomas and twelve were determined to be oxyphil adenomas, defined as containing at least $90 \%$ oxyphil cells. Eight samples from four patients were consistent with primary chief cell hyperplasia, involving multiple glands. None of the patients from whom tissue was obtained had a known history of head or neck irradiation, or a history of familial hyperparathyroidism or multiple endocrine neoplasia. One patient with primary chief cell hyperplasia had a his-
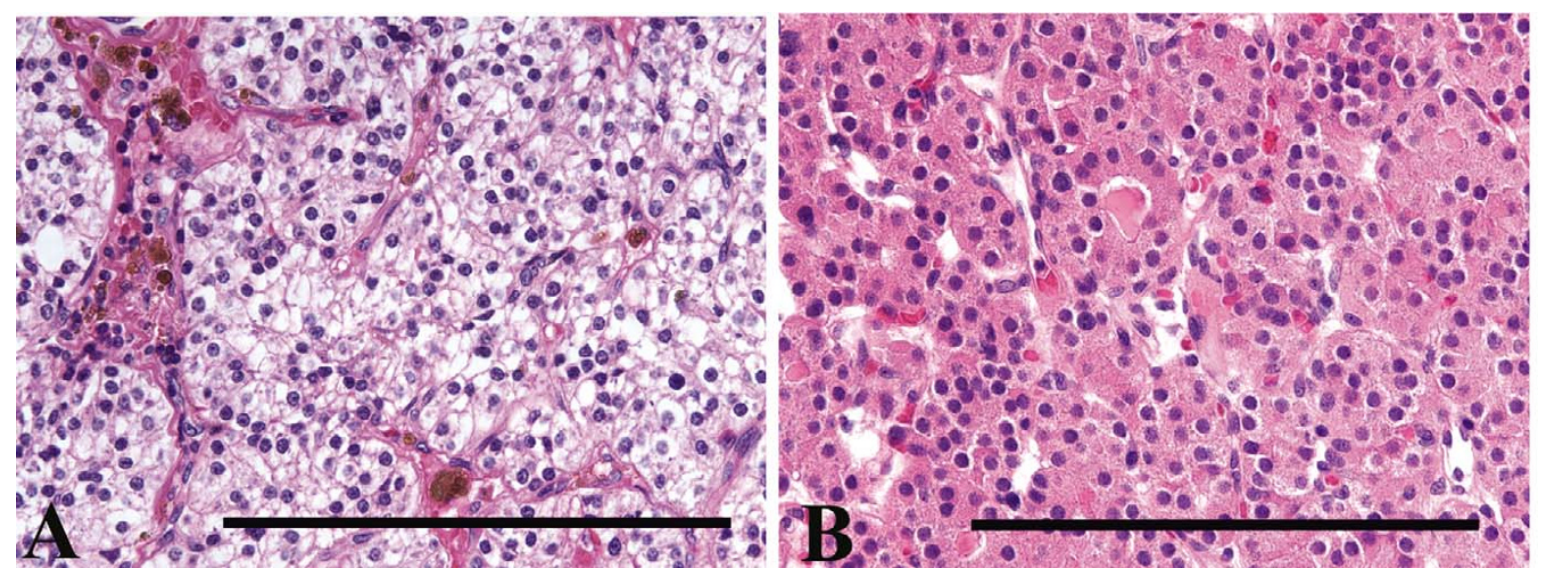

Figure I

The chief cells of an adenoma $(A)$ have an amphophilic, vacuolated cytoplasm, which on electron microscopic examination is composed of sparse mitochondria and the usual organelles associated with protein synthesis and secretion, glycogen and lipid [30]. Typical oxyphil cell adenoma (B) composed of large cells with a brightly eosinophilic granular cytoplasm, which on electron microscopic examination consists of densely packed mitochondria. The bar represents I $\mathrm{mm}$. 
tory of lithium use. After surgical removal, tissues were dissected and quickly frozen in liquid nitrogen before being stored at $-80^{\circ} \mathrm{C}$. Peripheral blood leukocyte samples were obtained from the same patients, to serve as non-parathyroid germline controls. Also included in this study were five normal parathyroid glands and one normal thyroid gland from five patients with primary hyperparathyroidism due to a single adenoma. One normal parathyroid gland and a normal thyroid gland were obtained on autopsy. The remaining normal parathyroid glands were obtained from patients who had the glands removed incidental to an operation for thyroid disease.

\section{Mitochondrial Genome Sequencing}

Genomic DNA was extracted from each sample using either proteinase $\mathrm{K}$ digestion for surgical samples or sucrose gradient centrifugation for blood samples, followed by phenol-chloroform extraction and ethanol precipitation.

The entire $16.6 \mathrm{~kb}$ mitochondrial genome from each parathyroid sample was amplified and sequenced. To avoid amplification of nuclear mitochondrial pseudogenes, the mitochondrial genome was amplified as per Polyak et al [8], as 8 overlapping 1-3 kb PCR products using a step down PCR protocol or as 11 overlapping PCR products described as follows: PCR reactions were performed in 20 $\mu \mathrm{l}$ reaction volume including $25 \mathrm{ng}$ DNA, $20 \mathrm{pmol}$ of each primer, $200 \mu \mathrm{M}$ each dNTP, 1.25 U of Amplitaq Gold DNA Polymerase (Applied Biosystems, Foster City, CA) and $1.5 \mathrm{mM}$ magnesium chloride; thermocycling consisted of an initial denaturation step of $95^{\circ} \mathrm{C}$ for $10 \mathrm{~min}$ utes, 35 cycles of $95^{\circ} \mathrm{C}$ for 30 seconds, $55^{\circ} \mathrm{C}$ for 30 seconds, and $72^{\circ} \mathrm{C}$ for 3 minutes, and a final extension step at $72^{\circ} \mathrm{C}$ for 10 minutes. For difficult to amplify templates, additional PCR primers were designed and are available on request. PCR products were either gel purified using the Qiagen gel extraction kit (Qiagen, Valencia, CA), or 10 U Exonuclease I and 1 U Shrimp Alkaline Phosphatase (Amersham Pharmacia Biotech, Piscataway, NJ). Purified PCR products were subjected to automated sequencing using the Big Dye Terminator Cycle Sequencing Ready Reaction Kit (Applied Biosystems). We also made and utilized additional sequencing primers, sequences available on request. Sequencing products were purified through Sephadex G-50 columns (Sigma-Aldrich, St. Louis, MO), and electrophoresed on $4.75 \%$ Long Ranger gels (BioWhittaker Molecular Applications, Rockland, ME) on an ABI Prism 377 Sequencer (Applied Biosystems).

To determine if sequence changes identified in patients with hyperparathyroidism were somatic and/or clonal, the corresponding mitochondrial genomic regions from the patient's normal control peripheral blood leukocytes were also sequenced as above. Resulting sequence data files were analyzed and compared with the standard Anderson mtDNA sequence using the sequence analysis programs Sequencing Analysis and Auto Assembler (Applied Biosystems). Deviations from the standard sequence were compared with the on-line Mitomap database of previously reported mtDNA mutations and polymorphisms [18]. All apparent somatic clonal mutations were confirmed by sequencing products of independent PCR reactions, and by sequencing the opposite DNA strand.

\section{Results}

A total of 393 homoplasmic sequence variants were identified (8-45 variants per sample) as compared to the standard Anderson mtDNA sequence [19]. Of the 393 variants, 375 were single base pair substitutions, 13 were single base pair insertions or deletions ( 4 deletions and 9 insertions), 2 were 2 base pair deletions, 2 were 2 base pair insertions and 1 was an 8 base pair deletion. Evaluation utilizing the mitochondrial database, Mitomap [18], indicated that of the 393 variants, 117 were in non-coding regions, 244 were in protein coding genes and 32 were predicted to affect rRNA or tRNA. Novel sequence variants are shown in Table 1.

Eleven somatic mutations were identified in 6 of 18 chief cell adenomas (Table 2 and Figure 2). Two tumors contained mutations that were predicted to result in early stop codons in either the ND4 or ND6 genes, both subunits of mitochondrial Complex I. Three tumors contained mutations that were predicted to result in non-synonymous changes in subunits of either Complex I or Complex III. Two tumors contained mutations only in the highly polymorphic, but non-coding D-loop region.

Sixteen somatic mutations were identified in 9 of 12 oxyphil adenomas. Four tumors contained mutations that were predicted to result in early stop codons in either the ND1, ND4 or ND5 genes, all subunits of mitochondrial Complex I. Two tumors contained non-synonymous changes in Complex I subunits, one tumor contained a mutation in CO1 not predicted to change the amino acid sequence and one tumor contained a mutation affecting a tRNA gene. One tumor contained a D-loop mutation only. All mutations appeared to be homoplasmic, with the exception of one, which appeared to be heteroplasmic, a G to A transition at position 559, within the D-loop region. Homoplasmy refers to the presence of a particular sequence variant or mutation in virtually every copy of the mitochondrial genome within a single tumor cell sample (and within the limits of sensitivity of the sequencing technology), while heteroplasmy refers to the presence of more than one such detectable allele [20]. Heteroplasmy within a tumor would be indistinguishable from homo- 
Table I: Novel germline sequence variants identified by this study

\begin{tabular}{|c|c|c|c|}
\hline Nucleotide position & Base Change & Region Affected & Expected Protein Change \\
\hline 1007 & $g-a$ & I2s rRNA & $\mathrm{n} / \mathrm{a}$ \\
\hline 1339 & $g-c$ & I2s rRNA & $\mathrm{n} / \mathrm{a}$ \\
\hline 2218 & $c-t$ & $16 \mathrm{~s}$ rRNA & $\mathrm{n} / \mathrm{a}$ \\
\hline 2639 & $c-t$ & I6s rRNA & $\mathrm{n} / \mathrm{a}$ \\
\hline 3159 & ins $t$ & I6s rRNA & $\mathrm{n} / \mathrm{a}$ \\
\hline 3198 & $a-c$ & I6s rRNA & $\mathrm{n} / \mathrm{a}$ \\
\hline 3511 & $a-g$ & NDI & 69 Thr-Ala \\
\hline 3719 & $a-g$ & NDI & 138 Gln-Arg \\
\hline 3826 & $\mathrm{t}-\mathrm{c}$ & NDI & no change \\
\hline 3867 & $c-t$ & NDI & no change \\
\hline 4296 & $\mathrm{t}-\mathrm{c}$ & Ile tRNA & $\mathrm{n} / \mathrm{a}$ \\
\hline 4674 & $a-g$ & ND2 & 69 lle-Val \\
\hline 4718 & $a-g$ & ND2 & no change \\
\hline 4735 & $\mathrm{c}-\mathrm{a}$ & ND2 & 89 Thr-Arg \\
\hline 5238 & $c-t$ & ND2 & no change \\
\hline 5250 & $\mathrm{t}-\mathrm{c}$ & ND2 & no change \\
\hline 5318 & $c-t$ & ND2 & no change \\
\hline 5463 & $c-t$ & ND2 & 332 Leu-Phe \\
\hline 6026 & $g-a$ & $\mathrm{COI}$ & 42 Gly-Asp \\
\hline 6339 & $a-g$ & $\mathrm{COI}$ & I46 Thr-Ala \\
\hline 6425 & $\mathrm{t}-\mathrm{c}$ & $\mathrm{COI}$ & no change \\
\hline 6570 & $g-t$ & $\mathrm{COI}$ & 223 Ala-Ser \\
\hline 6656 & $c-t$ & $\mathrm{COI}$ & no change \\
\hline 6775 & $a-c$ & $\mathrm{COI}$ & 291 His-Pro \\
\hline 7295 & $a-g$ & $\mathrm{COI}$ & no change \\
\hline 7744 & $\mathrm{t}-\mathrm{c}$ & COII & no change \\
\hline 7963 & $a-g$ & COII & no change \\
\hline 7966 & $c-t$ & COll & no change \\
\hline 8395 & $c-t$ & ATPase8 & no change \\
\hline 8515 & $c-t$ & ATPase8 & no change \\
\hline 8602 & $\mathrm{t}-\mathrm{c}$ & ATPase6 & 26 Phe-Leu \\
\hline 8953 & $a-g$ & ATPase6 & | 43 lle-Val \\
\hline 8987 & $t-g$ & ATPase6 & I 54 Met-STOP \\
\hline 9088 & $\mathrm{t}-\mathrm{c}$ & ATPase6 & I 88 Ser-Pro \\
\hline 9210 & $a-g$ & COIII & 2 Thr-Ala \\
\hline 9233 & $\mathrm{t}-\mathrm{c}$ & COIII & no change \\
\hline 9426 & $c-t$ & COIII & 74 Pro-Ser \\
\hline 9555 & $c-a$ & COIII & II 7 Pro-Thr \\
\hline 9614 & $a-t$ & COIII & no change \\
\hline 9656 & $\mathrm{t}-\mathrm{c}$ & COIII & no change \\
\hline 10152 & $g-c$ & ND3 & 32 Glu-Gln \\
\hline 10325 & $g-a$ & ND3 & no change \\
\hline 10754 & $a-c$ & ND4L & no change \\
\hline 10775 & $g-a$ & ND4 & $6 \mathrm{Val}-\mathrm{Ile}$ \\
\hline 10973 & $c-a$ & ND4 & 72 Leu-Ile \\
\hline 11151 & $c-t$ & ND4 & I3| Ala-Val \\
\hline 11354 & $\mathrm{t}-\mathrm{c}$ & ND4 & 199 Tyr-His \\
\hline 11566 & $a-g$ & ND4 & no change \\
\hline 11617 & $\mathrm{t}-\mathrm{c}$ & ND4 & no change \\
\hline 11911 & $c-a$ & ND4 & no change \\
\hline 11928 & $a-g$ & ND4 & 390 Asn-Ser \\
\hline 12879 & $\mathrm{t}-\mathrm{c}$ & ND5 & no change \\
\hline 12953 & $c-t$ & ND5 & $206 \mathrm{Ala}-\mathrm{Val}$ \\
\hline 12954 & $\mathrm{t}-\mathrm{c}$ & ND5 & no change \\
\hline 12976 & $c-g$ & ND5 & 214 Leu-Val \\
\hline 13129 & $c-t$ & ND5 & 265 Pro-Ser \\
\hline 13132 & $c-t$ & ND5 & no change \\
\hline 13260 & $\mathrm{t}-\mathrm{c}$ & ND5 & no change \\
\hline 13264 & $c-t$ & ND5 & no change \\
\hline
\end{tabular}


Table I: Novel germline sequence variants identified by this study (Continued)

\begin{tabular}{|c|c|c|c|}
\hline 13392 & $\mathrm{t}-\mathrm{c}$ & ND5 & no change \\
\hline 13422 & $a-g$ & ND5 & no change \\
\hline 13708 & $g-a$ & ND5 & 458 Ala-Thr \\
\hline 13743 & $\mathrm{t}-\mathrm{c}$ & ND5 & no change \\
\hline 14364 & $g-a$ & ND6 & no change \\
\hline$|458|$ & $\mathrm{t}-\mathrm{c}$ & ND6 & no change \\
\hline 14694 & $c-g$ & Gln tRNA & $\mathrm{n} / \mathrm{a}$ \\
\hline $148 \mid 4$ & $c-g$ & CYTB & 23 Thr-Ser \\
\hline 14869 & $g-c$ & CYTB & no change \\
\hline $15 \mid 48$ & $g-a$ & CYTB & no change \\
\hline 15172 & $g-a$ & CYTB & no change \\
\hline $1539 \mid$ & $c-t$ & CYTB & no change \\
\hline 15544 & $c-a$ & CYTB & no change \\
\hline 15629 & $\mathrm{t}-\mathrm{c}$ & CYTB & no change \\
\hline$|566|$ & $c-t$ & CYTB & no change \\
\hline 15697 & $\mathrm{t}-\mathrm{g}$ & CYTB & 317 Phe-Leu \\
\hline 15709 & $c-g$ & CYTB & 32I Ser-STOP \\
\hline 15783 & $c-t$ & CYTB & 346 Pro-Leu \\
\hline 16478 & $c-t$ & non-coding & $\mathrm{n} / \mathrm{a}$ \\
\hline $1652 \mid$ & $a-c$ & non-coding & $\mathrm{n} / \mathrm{a}$ \\
\hline
\end{tabular}

Table 2: Summary of somatic mutations identified in parathyroid adenomas

\begin{tabular}{|c|c|c|c|c|c|}
\hline Tumor ID & Tumor Type & Mutation & Gene affected & Expected Protein Change & Previously seen? \\
\hline 1 & Oxyphil cell & $|263| T>C$ & ND5 & 99Ser>Pro & normal variant \\
\hline \multirow[t]{3}{*}{2} & Oxyphil cell & $3173 G>A$ & I6S rRNA & & novel \\
\hline & & $6869 \mathrm{C}>\mathrm{T}$ & $\mathrm{COI}$ & no change & somatic mutation-cancer cell line \\
\hline & & I2425delA & ND5 & 30Asn>Frameshift & novel \\
\hline \multirow[t]{2}{*}{3} & Oxyphil cell & $559 \mathrm{G}>\mathrm{A}^{*}$ & D-loop & & normal variant \\
\hline & & $7028 \mathrm{~T}$ & $\mathrm{COI}$ & no change & normal variant \\
\hline 4 & Oxyphil cell & 3572ins C & NDI & 89Leu>Frameshift & novel \\
\hline 5 & Oxyphil cell & $15924 \mathrm{~A}>\mathrm{G}$ & Thr tRNA & & LIMM \\
\hline \multirow[t]{2}{*}{6} & Oxyphil cell & $304 \mathrm{C}>\mathrm{T}$ & D-loop & & normal variant \\
\hline & & Il038delA & ND4 & 93Lys >Frameshift & novel \\
\hline 7 & Oxyphil cell & 310 ins $C$ & D-loop & & normal variant \\
\hline 8 & Oxyphil cell & 3566insC & NDI & 87Thr>Frameshift & novel \\
\hline \multirow[t]{4}{*}{9} & Oxyphil Cell & $4 \mid 72 T>C$ & NDI & 289Leu>Pro & novel \\
\hline & & $5026 \mathrm{~A}>\mathrm{G}$ & ND2 & $186 \mathrm{His}>\mathrm{Arg}$ & somatic mutation-oral cancer \\
\hline & & $10522 G>A$ & ND4L & $18 \mathrm{Gly}>\mathrm{Glu}$ & novel \\
\hline & & $12372 G>A$ & ND5 & no change & normal variant \\
\hline \multirow[t]{3}{*}{10} & Chief Cell & Il038delA & ND4 & 93K > Frameshift & novel \\
\hline & & I3577T >C & ND5 & $4 \mid 4 \| \mathrm{e}>\mathrm{Thr}$ & novel \\
\hline & & | $4386 \mathrm{~T}>\mathrm{C}$ & ND6 & no change & normal variant \\
\hline 11 & Chief Cell & $|63| \mid T>C$ & D-loop & & normal variant \\
\hline 12 & Chief Cell & $12382 A>G$ & ND5 & $|6| l e>V a \mid$ & novel \\
\hline 13 & Chief Cell & I5578T>C & CYTB & 278Tyr $>\mathrm{His}$ & novel \\
\hline \multirow[t]{4}{*}{14} & Chief Cell & 8281 del8 & non-coding & & novel \\
\hline & & $12753 A>G$ & ND5 & no change & novel \\
\hline & & |4488delT & ND6 & 62Gly>Frameshift & novel \\
\hline & & $16519 T>C$ & D-loop & & normal variant \\
\hline 15 & Chief Cell & $253 C>A$ & D-loop & & somatic mutation \\
\hline
\end{tabular}

* indicates that this mutation appeared to be heteroplasmic LIMM-Lethal Infantile Mitochondrial Myopathy 


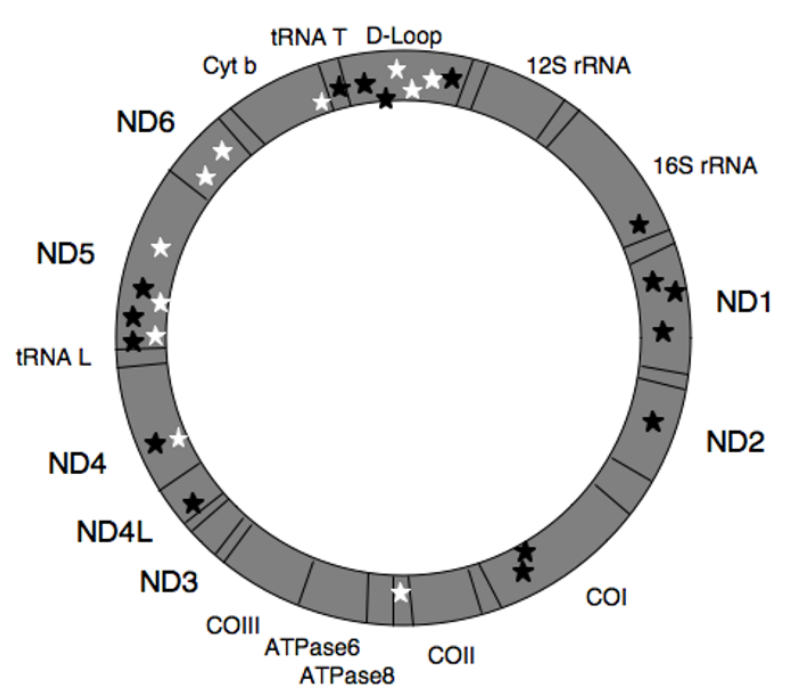

Figure 2

Schematic diagram of the mitochondrial genome including locations of the somatic mutations identified in this study. Locations of somatic mutations in parathyroid chief cell and oxyphil cell adenomas are indicated by white and black stars, respectively.

plasmy in a sub-population of the tumor's cells, since each tumor's cells are being analyzed collectively rather than on an individual cell-by-cell basis.

Mutations affecting Complex I genes, which represent $38.2 \%$ of the mitochondrial genome, accounted for $55.6 \%$ of all mutations and $22.2 \%$ of mutations occurred in the highly variable D-loop region.

To determine if the observed trend towards increased numbers of likely or potentially functionally significant mtDNA mutations in oxyphil adenomas as compared to chief cell adenomas was statistically significant, Fisher's Exact test was performed yielding a significant $\mathrm{p}$-value of 0.02 .

No somatic mutations occurred in any of the hyperplastic parathyroid glands. The one normal parathyroid for which paired thyroid tissue was available also contained no somatic mutations. No clustering of germline sequence variants occurred in any of the samples studied.

\section{Discussion}

Mitochondrial abnormalities have been observed in many cancers and previous studies have demonstrated altered energy metabolism in cancer cells [2-10]. Homoplasmic somatic mutations of the mitochondrial genome have been identified in various tumor types. The mitochondrial genome is an especially attractive potential target for mutations that could drive tumorigenesis in a low turnover tissue such as the human parathyroid, given the frequent replication of mitochondrial DNA, independent of the nuclear genome and the enhanced potential for mitochondrial DNA damage by ROS. One might expect an increased potential for accumulation of somatic mutations in the mitochondrial genome in such low replicative tissues as the parathyroid over many years. Our data provide initial support for these hypotheses, and suggest that other slow-growing tumors arising from low-replication tissues should be similarly analyzed.

Mitochondrial DNA mutations in parathyroid adenomas tend to affect Complex I genes more often than other tumor types and more often then expected by chance alone. Additionally, D-loop mutations appear to be underrepresented in parathyroid adenomas compared to other tumor types. In contrast to many other studies, this study rigorously examines the entire mitochondrial genome in matched tumor/normal pairs from the same individual while many analogous studies of other types of tumors focused primarily on coding regions and/or the Dloop region or used population rather than control DNA from the same patient. Due to the wide range of mutation frequencies in the literature and discrepancies in study design, statistical analyses between our data and those from other related studies cannot generally be performed. The importance of observed differences between parathyroid adenomas and other tumor types remains unclear.

Our results raise the possibility that NADH dehydrogenase subunit genes might play a key role in tumorigenesis, perhaps especially in low-replication tissues. Few studies have directly examined this issue. The contribution of specific mtDNA mutations, affecting the ATP synthase subunit 6 [21,22], to tumorigenesis has been examined, however little is known about the potential pathogenetic significance of the majority of mtDNA mutations identified to date. The contribution of specific germline sequence variants as predisposition alleles to specific tumor types has been suggested, however the majority of germline mtDNA sequence variants appear unlikely to directly contribute to tumorigenesis because of the frequency of such changes in individuals without tumors. Muller-Hocker, et al. examined respiratory chain function in normal parathyroid glands and hyperplastic parathyroids in uremic patients[23], finding defects in Complex III and IV in both normal and diseased glands. They also reported that chief cells in $20 \%$ of uremia-associated (secondary) hyperplastic parathyroid glands had defects of the respiratory chain, and that heart and muscle cells had more respiratory chain defects than parathyroid oxyphil cells. Together with reports of respiratory chain defects in normal, adenomatous, and hyperplastic parathyroid glands, the preferential clustering within NADH dehydro- 
genase subunit genes of the somatic mitochondrial mutations in our series of adenomas reinforces the intriguing suspicion that these mutations may be playing an integral role in parathyroid tumorigenesis. Given that mitochondria have recently been implicated in the regulation of intracellular calcium homeostasis $[24,25]$ and apoptosis [26], and that calcium sensing and signaling are crucial to parathyroid function and regulated PTH secretion, the possible relationship between calcium homeostasis and mitochondrial complex I enzyme function deserves further scrutiny.

Our data also provide additional support for the hypothesis that mitochondria accumulate in oxyphil cells due to abnormalities of the mitochondrial genome. Previous studies of Hurthle cell [27] and other oncocytic tumors [28] have demonstrated an association between a large deletion of mtDNA $(\Delta 4977)$ and oncocytic/oxyphilic tumors in comparison to non-oncocytic tumors of the same tissue type. However, given its presence in both normal and tumor cells of various tissues, the potential pathogenetic significance of such a finding remains unclear. As such, the presence or absence of this deletion was not addressed by our experimental approach and was considered beyond the scope of this manuscript. Functioning oxyphil cell parathyroid adenomas are more likely to contain somatic mtDNA mutations than chief cell adenomas and the somatic mutations in oxyphil adenomas are more likely to be functionally significant. These differences between oxyphil and chief cell adenomas are statistically significant with a p-value of 0.02 (Fisher's Exact Test). Our results show marked similarity to the recent findings in thyroid tumors by Gasparre et al that disruptive mutations (nonsense and frameshift mutations) in Complex I genes are associated with an oncocytic phenotype [29]. It is therefore quite plausible that these molecular genetic lesions may make key contributions to determining the oxyphilic phenotype, as mitochondria may increase their replication rate as a compensatory mechanism for altered energy metabolism due to mtDNA mutations. Further studies of normal oxyphil cells that could shed additional light on this hypothesis should be encouraged.

\section{Competing interests}

The author(s) declare that they have no competing interests.

\section{Authors' contributions}

JC-G participated in the design of the study, carried out molecular genetic studies and sequence analyses, and drafted the manuscript. TT participated in the design of the study and carried out molecular genetic studies and sequence analyses. SIR performed histological analyses for all tumor samples. AA participated in the design and coordination of the study, data analysis and interpretation. All authors participated in revising drafts of the manuscript, and all authors read and approved the final manuscript.

\section{Acknowledgements}

We thank Dr. Stephen J. Walsh for assistance with statistical calculations and Ms Teresa Kim for assistance with experiments.

This work was supported in part by grant DHHS/NIDCR 5T32-DE07302 from the National Institutes of Health and by the Murray-Heilig Fund in Molecular Medicine.

\section{References}

I. Yao K, Singer FR, Roth SI, Sassoon A, Ye C, Giuliano AE: Weight of normal parathyroid glands in patients with parathyroid adenomas. J Clin Endocrinol Metab 2004, 89(7):3208-32I 3.

2. Fliss MS, Usadel H, Caballero OL, Wu L, Buta MR, Eleff SM, Jen J, Sidransky D: Facile detection of mitochondrial DNA mutations in tumors and bodily fluids. Science 2000, 287(5460):2017-2019.

3. Habano W, Sugai T, Nakamura SI, Uesugi N, Yoshida T, Sasou S: Microsatellite instability and mutation of mitochondrial and nuclear DNA in gastric carcinoma. Gastroenterology 2000, I I 8(5):835-84|.

4. Jones JB, Song JJ, Hempen PM, Parmigiani G, Hruban RH, Kern SE: Detection of mitochondrial DNA mutations in pancreatic cancer offers a "mass"-ive advantage over detection of nuclear DNA mutations. Cancer Res 200 I, 6 I (4): I 299- I 304.

5. Liu VW, Shi HH, Cheung AN, Chiu PM, Leung TW, Nagley P, Wong LC, Ngan HY: High incidence of somatic mitochondrial DNA mutations in human ovarian carcinomas. Cancer Res 200I, 6 I ( I 6):5998-600I.

6. Parrella P, Xiao Y, Fliss M, Sanchez-Cespedes M, Mazzarelli P, Rinaldi M, Nicol T, Gabrielson E, Cuomo C, Cohen D, Pandit S, Spencer M, Rabitti C, Fazio VM, Sidransky D: Detection of mitochondrial DNA mutations in primary breast cancer and fine-needle aspirates. Cancer Res 200I, 6 I (20):7623-7626.

7. Penta JS, Johnson FM, Wachsman JT, Copeland WC: Mitochondrial DNA in human malignancy. Mutat Res 2001, 488(2): I 19-133.

8. Polyak K, Li Y, Zhu H, Lengauer C, Willson JK, Markowitz SD, Trush MA, Kinzler KW, Vogelstein B: Somatic mutations of the mitochondrial genome in human colorectal tumours. Nat Genet 1998, 20(3):291-293.

9. Sanchez-Cespedes M, Parrella P, Nomoto S, Cohen D, Xiao Y, Esteller M, Jeronimo C, Jordan RC, Nicol T, Koch WM, Schoenberg M, Mazzarelli P, Fazio VM, Sidransky D: Identification of a mononucleotide repeat as a major target for mitochondrial DNA alterations in human tumors. Cancer Res 2001, 6 I(19):7015-7019.

10. Yeh J], Lunetta KL, van Orsouw NJ, Moore FD Jr, Mutter GL, Vijg J, Dahia PL, Eng C: Somatic mitochondrial DNA (mtDNA) mutations in papillary thyroid carcinomas and differential mtDNA sequence variants in cases with thyroid tumours. Oncogene 2000, I 9( I 6):2060-2066.

II. Parfitt A: Parathyroid Growth: Normal and Abnormal. In The Parathyroids 2nd edition. Edited by: Bilezikian JP. San Diego: Academic Press; 2001:293-330.

12. Bogenhagen D, Clayton DA: Mouse L cell mitochondrial DNA molecules are selected randomly for replication throughout the cell cycle. Cell 1977, I I(4):719-727.

13. Hamperl H: [Onkocytes and onkocytoma.]. Virchows Arch Pathol Anat Physiol Klin Med 1962, 335:452-483.

14. Roth S, Belsley N, Abu-Jawdwh G: Histology for Pathologists 3rd edition. Edited by: Mills S. Philadelphia: Lippincott-WIlliams and Wilkins; 2006: I 149-1165.

15. Munger BL, Roth SI: The cytology of the normal parathyroid glands of man and Virginia deer; a light and electron microscopic study with morphologic evidence of secretory activity. J Cell Biol 1963, 16:379-400.

16. Apel R, Asa S: The Parathyroid Glands. In Endocrine Pathology Edited by: LiVolsi VAaSLA. Philadelphia: Churchill Livingstone; 2002: 103-147. 
17. Tallini G: Oncocytic tumours. Virchows Arch 1998, 433(I):5-I2.

18. Kogelnik AM, Lott MT, Brown MD, Navathe SB, Wallace DC: MITOMAP: a human mitochondrial genome database - 1998 update. Nucleic Acids Res 1998, 26( I): I I2-II5.

19. Anderson S, Bankier AT, Barrell BG, de Bruijn MH, Coulson AR, Drouin J, Eperon IC, Nierlich DP, Roe BA, Sanger F, Schreier PH, Smith AJ, Staden R, Young IG: Sequence and organization of the human mitochondrial genome. Nature 1981, 290(5806):457-465

20. Shadel GS, Clayton DA: Mitochondrial DNA maintenance in vertebrates. Annu Rev Biochem 1997, 66:409-435.

21. Petros JA, Baumann AK, Ruiz-Pesini E, Amin MB, Sun CQ, Hall J, Lim S, Issa MM, Flanders WD, Hosseini SH, Marshall FF, Wallace DC: mtDNA mutations increase tumorigenicity in prostate cancer. Proc Natl Acad Sci USA 2005, I 02(3):719-724.

22. Shidara Y, Yamagata K, Kanamori T, Nakano K, Kwong JQ, Manfredi $\mathrm{G}$, Oda H, Ohta S: Positive contribution of pathogenic mutations in the mitochondrial genome to the promotion of cancer by prevention from apoptosis. Cancer Res 2005, 65(5): $1655-1663$.

23. Muller-Hocker J, Aust D, Napiwotzky J, Munscher C, Link TA, Seibel $P$, Schneeweiss SG, Kadenbach B: Defects of the respiratory chain in oxyphil and chief cells of the normal parathyroid and in hyperfunction. Hum Pathol 1996, 27(6):532-54I.

24. Bernardi P: Mitochondrial transport of cations: channels, exchangers, and permeability transition. Physiol Rev 1999, 79(4): II27-II55.

25. Kowaltowski $\mathrm{AJ}$ : Alternative mitochondrial functions in cell physiopathology: beyond ATP production. Braz J Med Biol Res 2000, 33(2):24I-250.

26. Green DR, Reed JC: Mitochondria and apoptosis. Science 1998, 28 |(538I): | 309-|3|2.

27. Maximo V, Soares P, Lima J, Cameselle-Teijeiro J, Sobrinho-Simoes M: Mitochondrial DNA somatic mutations (point mutations and large deletions) and mitochondrial DNA variants in human thyroid pathology: a study with emphasis on Hurthle cell tumors. Am J Pathol 2002, I60(5): 1857-|865.

28. Lewis PD, Baxter P, Paul Griffiths A, Parry JM, Skibinski DO: Detection of damage to the mitochondrial genome in the oncocytic cells of Warthin's tumour. J Pathol 2000, I 9 I(3):274-28I.

29. Gasparre G, Porcelli AM, Bonora E, Pennisi LF, Toller M, lommarini L, Ghelli A, Moretti M, Betts CM, Martinelli GN, Ceroni AR, Curcio F, Carelli V, Rugolo M, Tallini G, Romeo G: Disruptive mitochondrial DNA mutations in complex I subunits are markers of oncocytic phenotype in thyroid tumors. Proc Natl Acad Sci USA 2007, I 04(2 I):900I-9006.

30. Roth SI, Munger BL: The cytology of the adenomatous, atrophic, and hyperplastic parathyroid glands of man. A light- and electron-microscopic study. Virchows Arch Pathol Anat Physiol Klin Med 1962, 335:389-410.

\section{Pre-publication history}

The pre-publication history for this paper can be accessed here:

http://www.biomedcentral.com/1472-6823/7/8/prepub http.//www.biomedcentral.com/1472-6823/7/8 